\title{
Fuel Efficiency in Aircraft and Its Financial Performance with Reference to Indian Airline Companies
}

\author{
Pradnya B. Bansod, Sanjaykumar Gaikwad
}

\begin{abstract}
The Airline business is mostly depended on aircrafts as aircrafts are most important asset for a company. The main focus of airline is to utilize the fuel efficiently as it is the biggest cost for a company. Hence utilizing fuel efficient aircraft becomes a necessity. This paper has an objective to study the aircrafts used by airline companies and which aircraft is found out to be most profitable to Indian airline context. The research is based on secondary data taken form authentic sources and analyzed using various methods. The conclusion is based on various calculation and comparison done on the data and observations. The research is in the context of Indian airline companies.
\end{abstract}

Keywords: Fuel efficiency aircrafts, Airline business, financial performance of aircrafts, performance of Airlines

\section{INTRODUCTION}

Airline business is totally depends upon the Aircrafts. The size of Airline Company is decided by how much aircrafts it has. Hence it is very important for an airline company to have a latest technology aircraft. Plus the Airlines has a biggest operating cost from this ATF i.e. airline turbine fuel. Hence having a fuel efficient aircraft becomes a necessity. In the transportation sector, refers to regulation that directly limits carbon dioxide emissions from an Aircraft, as opposed to restricting those emissions indirectly (through, e.g., fuel economy standards). This is called as Co2 emission standard. In year 2019, Sweden has started a campaign called "flygskam" means flying shame increasing scrutiny of the climate impact of flying has caused some to wonder about how much of their travel is justified, and others to prioritize local trips by train over long-haul flights. According to report published by IATA scheduled flights emitted more than 900 million tonnes (Mt) of carbon dioxide $\left(\mathrm{CO}_{2}\right)$ in 2018, more than the German economy and a $27 \%$ increase over the past five years alone. $\mathrm{CO}_{2}$ emissions from aircraft are on track to roughly triple by 2050 , at which time aviation may account for a quarter of global $\mathrm{CO} 2$ emissions if other sectors slash to the Paris goals. The United Nations has decided the Goals for airline companies for $\mathrm{CO} 2$ emission, despite that the aircraft companies are not being able to reach to it by fuel efficiencies.

Revised Manuscript Received on March 2, 2020.

* Correspondence Author

Pradnya Bansod*,Research Scholar,Managemnt department,Savitribai Phule Pune university,Pune Email:Pradnybansod@gmail.com*

Dr.Sanjay Gaikwad, Principal in PVG's College of Science, Pune

\section{LITERATURE REVIEW}

The aircraft efficiency is increasing by time even if the rate of efficiency is lower. A research paper based on topic airline fuel efficiency by author Zsuzsanna Csereklyei* David I. Stern Crawford (Csereklyei \& Stern, 2017) in 2017 briefs about the economic point of view of it. This paper has developed a model of economics. The data for around 1250 airlines has been gathered where the factors for airline to buy a fuel efficient aircraft is studied. The paper has identified that the airline if buys the aircraft with the new fuel efficient aircraft and considering the fuel saving on it hypothetically for about 10 years, also with the time value of money factor will give the really good return. There is also a mention of fleet fuel price affects a buying of new aircraft.

The finding of the paper is that larger and newer planes are more fuel efficient. Another finding was fleet fuel efficiency improves with the size of aircraft and price of fuel deteriorate with higher capital cost.

The research paper based on future direction of fuel efficiency in aviation industry (Maria, 2013) explains the author describes technological enhancements and inevitable measures for the improvement of fuel economy. The paper briefs those technologies that will allow the fuel utilization with modern aircraft's correct routing capabilities will enable the implementation of fuel-saving measures. Like at the time of landing and take offs. The fuel consumption and operational efficiency is clearly seen correlated according to the paper.Still due to various reasons like delay in flight, due padding and airborne delay increases the consumption. The paper has numerical calculation regarding fuel consumption in details. The results were as new generation aircrafts will be ready for year 2020 , the new aircrafts were reducing the fuel consumptions at least 25 to $35 \%$, but the performance will be dependent $10 \%$ on operational activities. The paper also throws a light on PW1100G Pure Power Engine which is new generation fuel efficient engine.

The fuel efficiency trends for new commercial aircrafts (Kharina \& Rutherford, 2015) are studied in the paper from 1960 to 2014. The paper is based on the variable fuel or passenger kilometer and average fuel burned. Then the paper has developed a reference line considering ICAO's Metric values and $\mathrm{CO} 2$ standard. The research objective was to refine estimates of new aircraft fuel efficiency from said period. Key results of the research was the overall historical trend, a comparison of new aircraft efficiency on the metrics said before, new trends in the fuel efficiency of all new aircraft vs. just new types. 
The paper also focuses on main drivers, especially fuel costs. The findings are as the trend is divided into two eras where in year 2000 the fuel efficient aircrafts were there and after the year 2010 again the trend goes back to old pattern. Means there is no annual improvement which is significant.

\section{OBJECTIVE}

- To identify different types of aircraft utilized by Airline companies.

- To find out the most fuel efficient aircrafts used by airline companies.

- To identify the most used type of aircraft by Indian airline Companies

- To identify most profitable aircraft out of the aircrafts utilized by Airline Companies.

\section{SCOPE}

The research paper is based on the facts finding related to airline fuel efficiency and its impact on financial performance. The scope of the study is limited to Airline industry which is using different types of aircrafts. The aircrafts are used same over a worldwide hence the study applies to all.

\section{RESEARCH METHODOLOGY}

The research is studying the types of aircrafts used in the recent years. The innovation in the aircrafts and airline companies using aircraft for improving financial performance. The airline data for the year 2017-18 for Indian Airline Company is analyzed like number of aircrafts used, aircraft names and number of departures happed during the year. The financial data is related to revenue generated by airline companies are analysed using financial methods.

\section{DATA COLLECTION}

The data studied is secondary data from various authentic journals and research papers for literature review and identification of aircrafts available in the market. Also reports from ICOA and IATA are studied. non scheduled revenue are taken form authentic website of government of directorate general of civil aviation. The data then analyzed using financial measures and conclusions are drawn according to that.

\section{LIMITATION}

Due to a wide scope to the subject all aspects could not be considered for the study. The period is considered to the recent times and old duration has not been studied in this paper. The data is considered for year $2017-18$.

\section{ANALYSIS}

The airline companies are solely dependent on the aircraft and its functioning. The companies either buy the aircraft or take it on lease. The company size is determined on how much aircraft it has and how many daily scheduled flights are there for the companies. The aircraft is the main
The airline data like fleet statistics and scheduled and

factor for industry. Hence fuel efficient aircraft has to be there if they want to survive.

Many factors affect airlines' decisions on the portfolio of planes they should hold and operate, including the average distance of the flights (long or short haul) usually flown, the fuel efficiency of the available aircraft, expected fuel prices (IEA, 2009), the price of new and used aircraft, financing requirements including owning vs. lease decisions.

\section{A. The aircrafts used by airline}

There are many types of aircrafts in the market. The companies who are manufacturing the aircrafts are situated in USA, UK and Germany mainly. Indian companies have to import the aircraft form these countries. The aircrafts comes in all shapes a, sizes and budgets. It totally depends on the budget of a company.

\section{B. The types of Aircrafts}

There are mainly four type of aircraft engines namely turbojet, turboprop, turbofan and turbo shaft.

A turbojet engine was first developed in Germany and England prior to World War II and is the simplest of all jet engines. Between 1939 and 1942, a Hungarian designer, Gyorgy Jendrassik designed the first turboprop engine. Then Rolls Royce converted this engine into actual working model in year 1945. When we combine the best of turbojet and turboprop we get turbofan engine. It was used first in military aircrafts. Next engine is Turboshaft which are predominantly used by helicopters it was built in France.

Family, A330 A turbojet engine was first developed in Germany and England prior to World War II and is the simplest of all jet engines. 1 Between 1939 and 1942, a Hungarian designer, Gyorgy Jendrassik designed the first turboprop engine. Then Rolls Royce converted this engine into actual working model in year 1945. When we combine the best of turbojet and turboprop we get turbofan engine. It was used first in military aircrafts. Next engine is Turboshaft which are predominantly used by helicopters it was built in France.

The different types of aircrafts are airbus, Boeing, Single-Engine Piston, business jets, helicopters, light sports aircrafts, Tiltrotors, Taildraggers Floatplanes or Seaplanes, Biplanes and Airships. Out of these commercially used aircrafts are Airbus and Boeing. The various categories of Airbus are A220 Family, A320 Family, A330 Family, A350 XWB family, A3802. Among all of these A220 Family aircraft have been specifically designed for the $100-150$ seat market type .It is said to be the fuel efficient aircrafts.

Boeing 777 is the aircraft having largest capacity around 400 seats. Boeing 747-400 is also said to be Family, A350 XWB family, A380. Among all of these A220 Family aircraft have been specifically designed for the 100-150 seat market type .It is said to be the fuel efficient aircrafts.

Boeing 777 is the aircraft having largest capacity around 400 seats. Boeing 747-400 is also said to be more fuel efficient aircraft widely used in Indian Airline companies.

\section{Fuel efficiency of aircrafts}

http://blog.covingtonaircraft.com $\underline{\text { https://www.airbus.com/aircraft.html }}$ 
There are four variants in A 320 family aircrafts like A318, A319, A320 and A321.The passenger capacity is around 100 to 240 seats. It is claimed to be spacious and fuel efficient aircrafts. This family is more popular in Airline companies.

A330 family these are variants like 200, 300, 800 and 900. The aircraft is said to be new generation aircraft. The specialty of this aircraft offers the lowest financial risk with the lowest seat mile cost of any wide-body in its category.

The A350 XWB family aircrafts are also said to be best for long haul type of operation which is also fuel efficient and modern in terms of space it offers in aircraft. There are two variants in this type of aircraft.

A 380 from Airbus has designed these aircrafts claiming largest and most spacious passenger aircraft in the world. But these type does not claim to be fuel efficient.

\section{DATA ANALYSIS}

There are around 37 types of aircrafts are utilized by Indian Airline Companies. The aircrafts are utilized for scheduled and non-scheduled passenger and Cargo carrier. The chart following shows that Indigo is having the highest nonscheduled revenue.

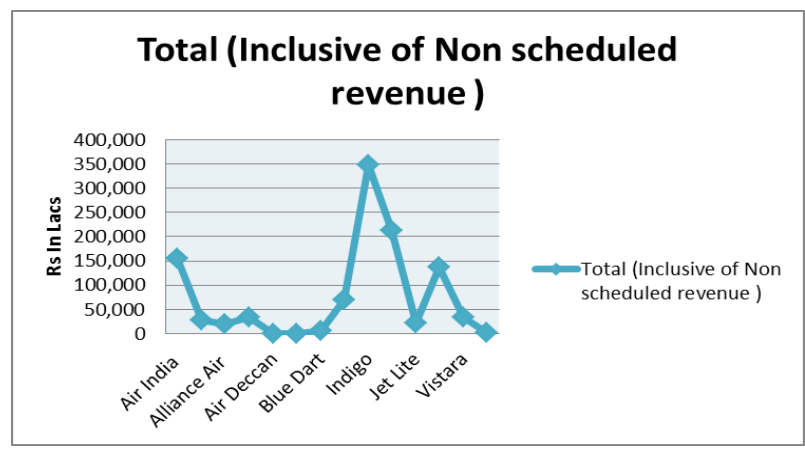

Figure 1: Total revenue of airlines from aircraft fleet utilization

Following table showing the different types of aircrafts utilized by Indian Airline companies and according the revenue generated which type of aircraft is most revenue generating aircraft.

Table I: Indian Airline Company utilizing Aircrafts and its frequency

\begin{tabular}{|l|l|c|c|l|}
\hline $\begin{array}{l}\text { Sr. } \\
\text { No. }\end{array}$ & $\begin{array}{l}\text { Name of an } \\
\text { Airline } \\
\text { company }\end{array}$ & $\begin{array}{l}\text { Number of } \\
\text { Aircrafts }\end{array}$ & $\begin{array}{l}\text { No of } \\
\text { Aircraft } \\
\text { types used }\end{array}$ & $\begin{array}{l}\text { Most revenue } \\
\text { generating Aircraft }\end{array}$ \\
\hline $\mathbf{1}$ & Air India & 121 & 7 & A-319 \\
\hline $\mathbf{2}$ & $\begin{array}{l}\text { Air India } \\
\text { Express }\end{array}$ & 23 & 1 & Boeing B 737- 800 \\
\hline $\mathbf{3}$ & Alliance Air & 16 & 2 & ATR-72-600 \\
\hline $\mathbf{4}$ & Air Asia & 16 & 1 & AIRBUS A320 \\
\hline $\mathbf{5}$ & Air Deccan & 3 & 1 & Beechcraft 1900D \\
\hline $\mathbf{6}$ & Air Odisha & 2 & 2 & $\begin{array}{l}\text { CESSNA } \\
\text { CARAVAN 208B }\end{array}$ \\
\hline $\mathbf{7}$ & Blue Dart & 6 & 1 & BOEING 757-200 \\
\hline $\mathbf{8}$ & Go Air & 32 & 2 & AIRBUS A320-214 \\
\hline $\mathbf{9}$ & Indigo & 159 & 2 & A320-200 \\
\hline $\mathbf{1 0}$ & Jet Airways & 111 & 6 & B- 737-800 \\
\hline $\mathbf{1 1}$ & Jet Lite & 7 & 2 & Boeing 737 - 800 \\
\hline $\mathbf{1 2}$ & Spice Jet & 60 & 4 & 737- 800 \\
\hline $\mathbf{1 3}$ & Vistara & 19 & 2 & A320-232 \\
\hline $\mathbf{1 4}$ & Zoom Air & 5 & 5 & $\begin{array}{l}\text { BOMBADIER } \\
\text { CRJ200LR } \\
\text {,MSN-7809, } \\
\text { VT-ZOA }\end{array}$ \\
\hline & & & & \\
\hline
\end{tabular}

Fig 2: Aircraft Airbus A320

Family and its percentage contribution

\begin{tabular}{|c|c|c|c|c|}
\hline $\begin{array}{l}\text { Name of } \\
\text { an Airline } \\
\text { Company }\end{array}$ & Name of an Aircraft & $\begin{array}{c}\text { Aircraft } \\
\text { revenue } \\
\text { contribution } \\
\text { (Rs. in } \\
\text { Lakhs) }\end{array}$ & $\begin{array}{c}\text { Total } \\
\text { Revenue } \\
\text { of a } \\
\text { Company } \\
\text { (Rs. in } \\
\text { Lakhs) }\end{array}$ & $\begin{array}{c}\% \text { of } \\
\text { Aircraf } \\
t \\
\text { Reven } \\
\text { ue } \\
\text { contrib } \\
\text { ution }\end{array}$ \\
\hline Air India & B-787 & 114,151 & 155,343 & 73.48 \\
\hline $\begin{array}{c}\text { Air India } \\
\text { Express }\end{array}$ & Boeing B 737- 800 & 28,850 & 28,850 & 100.00 \\
\hline $\begin{array}{c}\text { Alliance } \\
\text { Air }\end{array}$ & ATR-72-600 & 18,117 & 20,828 & 86.98 \\
\hline Air Asia & AIRBUS A320 & 33,127 & 33,127 & 100.00 \\
\hline $\begin{array}{c}\text { Air } \\
\text { Deccan }\end{array}$ & Beechcraft 1900D & 267 & 267 & 100.00 \\
\hline $\begin{array}{c}\text { Air } \\
\text { Odisha }\end{array}$ & $\begin{array}{c}\text { CESSNA CARAVAN } \\
\text { 208B }\end{array}$ & 564 & 608 & 92.76 \\
\hline Blue Dart & BOEING 757 - 200 & 6,148 & 6,148 & 100.00 \\
\hline Go Air & AIRBUS A320-214 & 69,140 & 69,140 & 100.00 \\
\hline Indigo & A320-200 & 345,282 & 347,640 & 99.32 \\
\hline $\begin{array}{c}\text { Jet } \\
\text { Airways }\end{array}$ & B-737 - 800 & 136,785 & 211,964 & 64.53 \\
\hline Jet Lite & Boeing 737 - 800 & 12,747 & 22,105 & 57.67 \\
\hline Spice Jet & B $737-800$ & 67,010 & 138,318 & 48.45 \\
\hline Vistara & A320-232 & 28,216 & 33,045 & 85.39 \\
\hline Zoom Air & $\begin{array}{c}\text { BOMBADIER } \\
\text { CRJ200LR ,MSN-7809, } \\
\text { VT-ZOA }\end{array}$ & 748 & 1196 & 62.54 \\
\hline
\end{tabular}

From the above table the observed things are Airbus A 320 Family aircrafts and Boeing B-737 family aircrafts are highest contributing into the airline percentage wise scheduled revenue for overall. The aircraft manufacturing giants Airbus and Boeing are giving fuel efficient market leader aircrafts. Further to analyse which aircraft is contributing to more of overall group revenue for airline companies researcher has analysed overall group performance of these two aircrafts as follows.

\section{Airbus A320 Family Aircrafts}

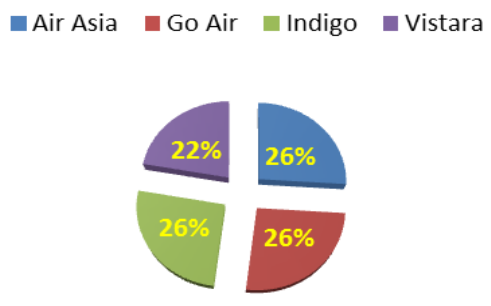

Blue Eyes Intelligence Engineering \& Sciences Publication 
The above pie chart depicts that the among the total revenue generated by airline companies using Airbus A320 family aircrafts like A320, A320-214, A 320-200 and A320-232.The aircrafts are contributing almost similar percentage to all the four companies which are using it. These aircrafts using fly-by-wire technology comes with a unique CLS option: it is the only single-aisle aircraft that is able to load pallets and containers on the lower deck.

\section{Boeing B 737 Family Aircraft}

\#ir India Express $\quad$ Jet Airways $\quad$ Jet Lite $\quad$ Spice Jet

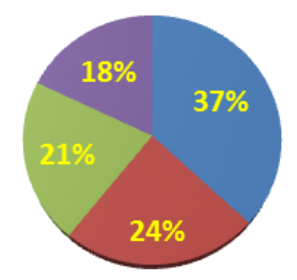

Fig 3: Aircraft Boeing B737 Family and its percentage contribution

The above pie chart depicts an idea about the aircrafts used by four airlines and variants used are only one which is B 737-800. Air India express is using only this aircraft for whole operations. The percentage contribution is quite a different form Airbus A320 family. It is said that B737 family is more popular than A 320 family because of discounts and speed of an Aircraft. It is also more fuel efficient and preferred for long distance journey.

If a comparison is done between Airbus A320 family and Boeing B 737-800 family a researcher found that overall scheduled and nonscheduled revenue from using A 320 family aircrafts by Indian airline companies is Rs.245,392 Lakhs as against B 737-800 family is Rs.475,765 Lakhs. These figures shows that B737-800 aircrafts are most revenue generating and profitable.

\section{FINDINGS:}

- The Indian Airline companies are using variety of aircrafts as of now.

- Two aircraft manufacturing companies are world leader in manufacturing fuel efficient aircrafts namely Boeing and Airbus.

- There are A320, A330 and A350 XWB family aircrafts are said to be fuel efficient.

- The company having highest number of aircrafts i.e. 159 is Indigo with only two variants of aircraft.

- Total scheduled revenue earned by utilizing aircraft is highest for Indigo Company which is using A 320 family aircraft.

- The most used aircrafts by airline companies are A 320 family and B737-800.

- Four Airline companies are using only one type of aircraft.
- The most profitable and profit contributing aircraft type is B737-800 of Boeing company.

\section{CONCLUSION}

The research paper has taken the recent data for analysis of financial data of Indian airlines and aircraft fleet data. The paper has studied the fleets utilized and frequency of fleets. The companies which are using less variants and more number of only one or two variants are used are more improved performance. These improvements may arise from hedging, improved scheduling, optimal pricing, and the through the replacement of old vintage airplanes in the fleet with advanced technology aircraft. The companies which are using fuel efficient aircraft of a Boeing B-737-800 had been a choice for long distance journey. For domestic operation A 320 family aircrafts are more suitable. The airline profitability depends upon selection of aircraft and its utilization for different type of journey.

\section{REFERENCES:}

Research papers and Journals:

1. Csereklyei, Z., \& Stern, D. I. (2017). Airline Fleet Fuel Efficiency. Retrieved from

ttps://www.monash.edu/_data/assets/pdf_file/0003/1168401/Zsuszann a.pdf

2. Kharina, S., \& Rutherford, D. (2015). Fuel efficiency trends for new commercial jet aircraft: 1960 to 2014. (August), 27. Retrieved from https://www.theicct.org/sites/default/files/publications/ICCT_Aircraft-F E-Trends_20150902.pdf

3. Maria, M. (2013). Future directions of fuel efficiency in aviation industry. Incas Bulletin, 5(4), 71-86. https://doi.org/10.13111/2066-8201.2013.5.4.8

Books:

1. Peter Morrell Airline Finance: Text, USA, Ashgate Publishing, Ltd., 2007

2. M.Y. Khan P K Jain Financial Management: Text, Problems and Cases [Book]. - New Delhi : McGraw Hill, 2006.

Web reference:

1. https://science.howstuffworks.com/transport/flight/modern/question192. htm

2. https://theicct.org/blog/staff/work-travel-in-the-age-of-flygskam-2019

3. https://wingsoverkansas.com/features/a1037/

4. https://www.airbus.com/aircraft.html

\section{AUTHORS PROFILE}

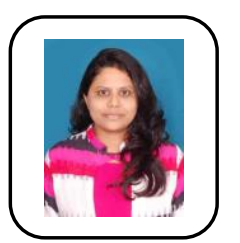

Pradnya B. Bansod, An Author is an assistant professor at Pune University affiliated college. She is pursuing her Ph.D. in Financial Management form SPPU. She has published 15 researcher papers till now. Her academic experience is of 8 years approved by SPPU.

Sanjaykumar GaikwadAuthor is working as a Principal in PVG's College of Science, Pune, have experience of more than 24 years in the field of academic , out of which more than 12 years as a Director \& Principal with reputed Colleges/Institutes. He is Ph.D. Research Guide in Commerce \& Management at SPPU. There are several research papers presented and published to his credit. 